\title{
A Comparative Study on Zakat Management Law Practices between Malaysia and Indonesia
}

\author{
Irma Rachmawati Ma'ruf ${ }^{1}$, Ali Anwar Jusuf ${ }^{2}$, Ram Al Jufri ${ }^{3}$, Juniardi Swastria ${ }^{4}$, \\ Dhani Supriadi ${ }^{5}$, Ponirah Kartika Rahayu ${ }^{6}$, Aang Arifin ${ }^{7}$ \\ 1,2,4,5,6,7 Universitas Pasundan, Bandung, Indonesia \\ ${ }^{3}$ University Utara Malaysia, Malaysia \\ Email: irma.rachmawati@unpas.ac.id
}

\begin{abstract}
Zakat management, that is collection and distribution funds, is an important to economy and society, in countries like Indonesia, Malaysia. They are controlled by government, which dictates the administration and management of zakat institutions. One of the issues is the level of zakat distribution is lower than the zakat collection. Hence, there are surplus of millions of zakat funds that are not distributed to the recipients. The purpose of this study is to identify the factors that lead to zakat as a productive asset and increase, and to explore and examine the management of zakat institutions in Malaysia, Indonesia and Singapore. The methodology used is a qualitative analytical description which analyze key provision of relevant law impacted upon the law of management zakat in Indonesia, Malaysia, and Singapore. The research is conducted by comparative approach. Based on the results of this study, the law of management zakat in Malaysia is better, however the management of zakat in Indonesia is better in distributions.
\end{abstract}

Keyword: Collection, Distribution, Law of Management Zakat.

\section{A. INTRODUCTION}

The payment of zakat is one of the five pillars in Islamic principle. Zakat is an important mechanism for the development of the country as it contributes to social security and harmony to help bridge the gap between the rich and the poor as well as to strengthen the economic independence of the Muslim community. It is also an important financial resource for an Islamic state in addition to the tax funds. Generally speaking, the distribution of zakat funds could help the government to generate economic activity through an increase in individual's purchasing power and finally help to alleviate poverty. Zakat funds can help the government in combating poverty through the Government Transformation Plan (GTP), NKRA Raising Living Standards of LowIncome Households. Zakat funds could be used to improve the living standards of the people who have low income households.

Given the importance of zakat to the economy and society, in countries like Malaysia, zakat institutions have been set up to collect and distribute funds. They are under the control of Islamic Religious Councils (IRC) of each state. The IRC play an important role in the administration and management of zakat institutions. Empirical evidence indicates that Malaysia's zakat collection has been increasing from year to year and the means of the distribution of zakat has become a model for other Muslim 
countries (Wahid and Kader, 2010). Zakat instutions as a non-profit financial institution has several direct impacts on the economic system (Khan, 1995 as cited in Norazlina \& Rahman, 2011) and is regarded as a complement to the financial institutions and as part of a comprehensive Islamic economic system.

There are three objectives of the study which are: 1 . To identify factors that lead to zakat surplus and its increment. 2. To explore and examine the accountability practices of zakat institutions in Malaysia and Indonesia. 3. To examine the effect of the system or practices of accountability on zakat surplus.

\section{Problem Statement}

Some recent studies, however, revealed many shortcomings of the zakat institutions (see, for example, Norazlina \& Rahim, 2011). One of the issues is the surplus of millions of ringgits of zakat funds that are not distributed to the recipients. Reports on zakat collection and distribution in Malaysia from 2010 to 2012 show that the performance of zakat distribution is fairly low as compared to zakat collection. For 2010, the amount of zakat collection across the country is RM 1,363.4 million and this number had increased up to RM1,634.5 million in 2011 and increased by RM1,922.8 million in 2012. Of this amount, the amount of funds distributed yield inconsistent with the amount collected. For example, for the year 2010, only RM 1,179.8 million has been distributed and leaving the sum of RM183.6 million that are not distributed. The total amount of undistributed zakat funds had increased significantly in 2011 when there were surplus of funds of RM261.9 million.

For the year 2012, a total of RM345.8 million undistributed zakat funds. The breakdown by states also shows the same trend. For the Federal Territory as example, the number of undistributed zakat funds for the year 2010 stood at RM82.1 million (29.1\%), RM100.8 million (29\%) in 2011, RM138.5 million (33.7\%) in 2012. For the state of Pahang, the number of zakat collection for 2010 was RM80.9 million, but the total distribution of zakat made just RM58.6 million. Similarly, in 2011 and 2012 recorded a total of $29.2 \%$ and $33.5 \%$, respectively, undistributed zakat funds. Despite the increasing surplus of funds from year to year, the current understanding on the zakat funds surplus particularly on the factors that cause it occurrences and increments is limited.

The zakat literature have six focused on identifying determinants of zakat compliance behaviour (Kamil, Zainol \& Jaffri, 2012; Jaffri, Kamil \& Zainol, 2010; Hairunnizam, Sanep \& Ali, 2007), zakat localization (Hairunnizam, Sanep \& Radiah, 2012a: 2012b; 2012c) and distribution of funds (Mahyuddin \& Abdullah, 2011; Muharman et al., 2011; Hairunnizam, Sanep \& Radiah, 2010; 2009; Ataina \& Achmad, 2010). Another stream of research focuses on issues related to zakat institutions which include efficiency and governance (Azman \& Syed, 2012; Norazlina \& Rahim, 2011).

Reviewing the current literature, we find the following major gaps: first, most zakat literature focuses on zakat compliance behaviour, zakat distribution and 
efficiency and governance of zakat institutions. The issue of zakat surplus has been neglected in the zakat literature. Second, little is known about why zakat surplus is keep increasing from year to year and how do zakat institutions manage this surplus. Third, there is little study that have been conducted to explore and examine zakat institutions accountability system or practices. Finally, to the best of our knowledge, there is little or no study has been conducted to examine the issue of zakat surplus and how this aspect/issue may be related to zakat institutions accountability system or practices

Our study aims to narrow these gaps. First, we focus on new issue related to zakat institution which is zakat surplus. Second, we will also focus on accountability system and practices of the zakat institutions. This study is among a few studies which try to examine the concept of accountability in religious-based organizations. Third, we will investigate the effect(s) of accountability practices on zakat surplus management.

\section{B. LITERATURE REVIEW}

Zakat, or also known as Islamic religious tax, is one of the pillars of Islam that must be met by the Muslims who are eligible. According to Islamic history, the word zakat has two different connotations. In terms of language, the word zakat comes from the root of Arabic word of zakat. Qardawi (1988) clarify that zakat means mercy, grown, clean, good, and be proud of. In terms of terminology, zakat means some specific properties that are required by Allah SWT to be given to those who are entitled (Qardawi, 1988). This means that zakat is a blessing, purity, kindness, and progress on the property after the payment of tithes was made at a certain rate and be distributed to its entitled recipient. As clearly stated in the Quran (Surah At-Taubah, 60), there are eight people who are eligible to receive zakat funds, i.e. the poor, the needy, zakat administrators, those whose hearts are inclined towards Islam (including the new converts to Islam who lack of economic support), slaves, debtors (debt due to the real needs), in the way of Allah (fi sabilillah), and wayfarers (ibnu sabil).

The objectives of zakat are twofold. Spiritually, paying zakat purifies and cleanses something from dirt or filth. Thus, individual who pay zakat is said free from having a bad habits such as greed, selfishness, and arrogance (Barizah, 2007). Economically, paying zakat will give a good effect on several economic dimensions, such as aggregate consumption, savings and investment, aggregate supply of labor and capital, poverty reduction and economic growth (Barizah \& Rahim, 2011). Zakat funds are also an important source of finance for Islamic countries besides tax funds (Diabi, 1993). Thus, zakat could help generate the prosperous society through redistribution of income between the rich and the poor and increase the individual's purchasing power parity. 


\section{Zakat Management}

Zakat management has been argued as the most critical aspect in determining the direction of the zakat institutions as a systematic and efficient management would ensure optimization of the zakat (Mutiara, Zakaria \& Zahri, 2013). Generally, management of zakat has been understood to involve two activities which are collection and distribution of zakat funds (Ahmad, 2009). One main objective of zakat management is to achieve the best possible outcome in the timely collection and distribution of zakat as ordained in Islamic Shariah (Quddus, 2009, p.316). Zakat management is important to help Muslims perform the third pillar of Islam and establish its primary function as a means to alleviate poverty (Quddus, 2009). Moreover, the effectiveness of zakat management is important to enable zakat to be a catalyst in improving the lives of the poor and needy (Mahyuddin \& Abdullah, 2011).

A sufficient level of trust is crucial to be maintained between Muslims and zakat institutions or otherwise the potential zakat payers would prefer to pay out zakat directly, for example to the poor or needy, rather than through the zakat institutions (Abdul Quddus, 2009). On the other hand, it has been argued that the zakat management should exhibit professionalism and trust to maintaining the interest of zakah recipients (Ataina \& Achmad, 2010). A considerable number of prior studies on zakat management (see, for example Sari, Bahari \& Hamat, 2013; Abdullah, 2010; Hudayati \& Tohirin, 2010; Lessy, 2009; Oran, 2009; Suhaib, 2009) have been carried out, conceptually and empirically, from various angles. One stream of research focuses on the issue of zakat compliance behaviour. For example, Jaffri (2010) conducted a study to find out determinants of zakat on business compliance behaviour. They found that factors such as attitude, subjective norm and perceived behavioral control are importants factors that shaping business man decision to pay zakat. Another focus of research is zakat distribution (see, for example Mahyuddin \& Abdullah, 2011; Ataina \& Achmad, 2010; Muharman et al., 2011).

Mahyuddin \& Abdullah (2011) argue that a more proactive mechanism, whether in form of monetary capital or equipment is vital to help recipients to improve their standard of living. They opine that a more self-sustained mechanism of zakat distribution could become the most effective tool that guarantees better quality of life for the zakat beneficiaries. On the other hand, by exploiting the technology Muharman et al. (2011) propose an integrated information system that could help to improve the zakat management. Meanwhile, there are a few previous studies which propose the collaboration between zakat institutions with microfinance institutions in order to improve the efficiency of zakat distribution (see, for example, Nur Bani, Abdul Halim \& Noor Ashikin, 2012; Yumna \& Clarke, 2011). Another stream of research focuses on issues related to zakat institutions (see, for example, Azman. Mohamad \& Syed, 2012; Norazlina \& Abdul Rahim, 2011). Azman's et al. (2012) work identifies and explores some problems and issues, which include for example inefficiency and capacity 
building, of zakat institutions in Malaysia in a great detail. They believe that spirit to uphold Islam as a religion for all humanity spirit must be the foundation of operating the zakat institutions because it would enhance their well-being and quality of life, provides employees a sense of purpose, meaning at work, a sense of interconnectedness and community (Azman et al., p.41). On the other hand a conceptual framework that could be used to evaluate the efficiency and governance of the zakat institutions in Malaysia was proposed by Norazlina \& Rahim (2011). They argue that such evaluations are crucial for the Islamic financial system to function effectively in order to achieve the noble objectives of socio-economic justice through proper distribution of wealth (Norazlina \& Rahim, 2011).

Prior studies on zakat management that were reviewed here have provided us with various useful insights about issues and challenges surrounding the management of zakat fund. A number of recommendations including models or framework were proposed to improve particularly the distributions of zakat. Despite these suggestions, as stated earlier one of possible effects of the inefficiency of zakat management is the issue of surplus of zakat funds which are not allocated to eligible recipients. While there are prior studies that suggest ways to overcome the inefficiency of zakat distribution there is little empirical studies, however, have been undertaken on this issue by examining the zakat institution's accountability system and practices. Depth understanding over the accountability system and practices of zakat institutions may help the study to identify underlying factors that lead to inefficiency in zakat distribution. Identifying underlying factors that lead to 8 inefficiency in zakat distribution might help zakat institutions to undertake necessary steps in improving, for example, procedures and/ or processes of zakat fund distribution.

The discussion on Islamic accountability can be seen in a wider perspective that it involves the one's relationship with Allah and to other human beings. ,Ignominy has been pitched on them, wherever they are, they shall get no security save a rope from Allah and a rope from men, (they may get protection). '(Surah Ali 'Imran: Verse No

112) The relationship to Allah can be counted through the word ,hisab', which is repeated in the Al-Quran for more than eight times (Askary \& Clarke, 1997). The word , hisab' reflects , account', which brings a universal sense relating to one's obligation to account to Allah and to other mankind. In this sense, every Muslim has an ,account 'with Allah, in ,recording' all good and bad deeds, which will continue until the death.

And, for Allah, the accounts for all his servants will be delivered to the mankind on the day of judgement. ,To Allah belongs whatever is in the heaven and whatever is in the earth; and if you disclose whatever is in your 9 heart or keep it hidden, Allah will call you to account for it; then He will forgive whomsoever He pleases and punish whomsoever He pleases, and Allah is potent over everything. ' (Surah Al-Baqara: Verse No 284) ,And how many a city rebelled against the Commandments of its Lord and His 
Messengers then we took a severe account from it, and gave it a horrible punishment.' (Surah At-Talaq: Verse No 8).

Additionally the relationship with Allah is deliberated by Lewis (2006), the concept of accountability in Islam is derived from the concept of Tauhid (the unity of Allah). The concept of the unity of Allah implies total submission to Allah's will and following the religious requirement in all aspects of life (Maali, Casson \& Napier, 2003). Baydoun \& Willett (2000) said that the concept of the unity of Allah gives rise to different and broader concept of accountability that implied by the Western models. The verse ,Allah takes careful account of everything' (Surah An-Nisa': Verse 86) reinforces the notion that everyone is accountable to

Allah on the day of judgement for their actions during their lives. In Islamic foundation, accountable to Allah implies accountable to society, which emphasized on rights of others. This can be concluding in the second discussion, which concerns the relational obligation to the mankind. In Islam, the rights and obligations of individuals and organizations with respect to each others are clearly defined. Thus, responsibilities definition in Islam is well-defined and stable, do not change or irrelevant over time or places because it's derived from Allah and Prophet Muhammad (peace and blessings be upon him) (Haniffa, 2002; Lewis, 2006). In understanding the relationship between the community, Islam concerns for the social environment and the way one's engage with other people (Kamla, Gallhofer, \& Haslam, 2006). The term brotherhood (ukhuwwah) in Islamic societies is a clear example of the importance of social responsibility in Islam. Muslims are supposed to take care of others in society - the Prophet Mohammad (peace and blessings be upon him) said, ,the Muslims in their mercy towards each other are like a body, if single part of it complains the other parts would be affected ' Al-Bukhari and Muslim). Muslim cannot (in good faith) compartmentalise their behaviour into religious and secular dimensions and their actions are always bound by the Shariah based on Quran and Sunnah.

Thus, submission to the Allah includes recognizing the rights of others and the involvement of oneself to the society justly (Maali, Casson, \& Napier, 2006). This can be verified through the verses in the Al-Quran, which provide the relational factor between Allah and other mankind. ,Undoubtedly, in the creation of heavens and earth and in the mutual alternation of night and day, there are signs for men of understanding. Who remember Allah standing and sitting and lying on their sides, and contemplate in the creation of heavens and earth; (saying) "O our Lord! You have not made it in vain, hallowed be You, You save us from the torment of the Hell. ' (Surah Ali 'Imran: Verse No 190-191) Therefore, this theoretical foundation for this study is based on the Islamic accountability, which stems the relationship of human and Allah and the relationship of human to other mankind. By referring to this notion, we believe the study will delineate the ultimate relationship of zakat institutions where it involves the relationship of the agency members with the Allah that is based on moral imperatives 
and values in oneself and the relationship with other community at large - including 'Asnaf' and the zakat payers. We believe the moral imperative and values is built in the Islamic moral foundations that individual has to undertake in fearing of Allah, honesty, trust, keep-promises, cooperation and forgiveness. ,Undoubtedly, Allah bids justice and good doing and giving to kindred and forbids indecency and wicked things and rebellion. He admonishes you that you may be mindful.' (Surah An-Nahl: Verse No 90) For one's good and bad deeds to Allah and mankind shall retain in the account of Allah on the judgement day. ,Then as to one who is given his record in his right hand. He will soon have an easy reckoning. ' (Surah Al-Inshiqaq: Verse No 7-8) In summary, the Islamic accountability theoretical foundation underpins the relationship between human and 10 one's and one's Creator, Allah, and other mankind (Gambling \& Karim, 1986; Haniffa, 2002; Lewis, 2006).

\section{METHOD}

In collecting data two methods will be employed which are semi-structured interview, and document review. In particular, data for the first research objective will be collected using semi- structured interviews with General Manager or Director of zakat institutions and economic scholars. Zakat institutions could be categorized into three different types of managements, (i) Fully-Corporatized zakat management entities, (ii) Semi Corporatized zakat management entities, and (iii) as part of the State Islamic Religious Council. Thus, for the purpose of interviews, the study will approach at least one zakat institution from each category.

Meanwhile, data for the second and third research objective will be gathered using both semi- structured interviews and documentation review methods. This research also used Law and acts as primary data. The method of this research is to make analysis of key provisions of relevant laws upon the response of interested parties (Rachmawati \& Supardi, 2019).

The interviews will be conducted with four zakat institutions' officers from the three zakat institutions who involve with, for example, the preparation of accountability mechanisms such as zakat institutions reports. The interviews will be designed to instigate a conversation, for example, about zakat distribution, zakat surplus, what accountability means to them, who are the stakeholders, how they practice and discharge their accountability. The brief outlines of issues or the interview guide (Morgan \& Smircich, 1980) will be sent out to all the respondents in advance prior to the interviews. Thus, the interviewees will have at least a rough idea about the issues to be discussed in the interview. All interviews will be recorded, with the permission from the interviewee, that is later transcribed and field notes are prepared. In addition, a review of the tape recorded reflections and field notes after the first two or three interviews and detailed review of the documentation will be undertaken to help the researcher to build an initial pattern of issues for probing subsequent interviews. 
The study will also review, extensively, a set of different documents, for example, zakat institution's annual reports, press releases, zakat institution's websites amongst others. The evidence that is going to be collected will come from various sources, mainly from the organizations' websites, the organizations' library/collection, and local newspapers.

\section{RESULT AND DISCUSSION}

This study will, therefore, draw upon Islamic accountability framework to address the empirical findings. It is essential to discuss on the selection Islamic accountability framework as compared to the Western thought in this section. With this in mind, the differences between Western thought and Islamic accountability can be seen from the view of recognizing, responsibilities'. As argued by Gray et al. (1987), identifying the responsibility of any organization is problematic because responsibility changes over time and from place to place and there is no agreed answer to the question of who determines what responsibilities exist. On the other hand, in Islam, the rights and obligations of individuals and organizations with respect to others are clearly defined by religion, and are neither imposed by secular law that is exposed to change, nor subject to personal views.

From an Islamic standpoint, this is considered to make Islam a stronger and more effective basis for ethical values. Despite the presence of many schools of thought in Islam, there is agreement on basic matters of principle (Hamid et. al, 1993, p. 136). Responsibilities of members of society to each other are well defined, do not change over time and are not affected by different theoretical frameworks. This makes definitions of responsibilities stable without being static and hence potentially irrelevant in other places or times. Islam claims to be a religion relevant for all times and places. In addition, in the Islamic context, the social responsibilities of individuals that are derived from the word of Allah (contained in the Qur'an) and from his prophet Mohammed's deeds and sayings (the Sunah) also apply to firms. Similarly, the main purpose of an Islamic business is to satisfy the will of Allah, through following the Qur'an and Sunah. Islam considers work to be part of the worship of Allah (Haniffa, 2002; Haniffa \& Hudaib, 2004).

Meanwhile in Indonesia, Under the Act. RI. No. 23 of 2011 article 1 paragraph 1 states that the management of zakat is the activity of planning, implementing, and coordinating in the collection, distribution, and utilization of zakat. To implement zakat management, the Indonesian government established the National Amil Zakat Agency (BAZNAS). BAZNAS is based in the nation's capital. BAZNAS is a nonstructural government institution that is independent and responsible to the President through the Minister. BAZNAS has the following functions; Planning of collection, distribution and utilization of zakat; Implementing of collection, distribution 
and utilization of zakat; Controlling of collection, distribution and utilization of zakat; Reporting and accountability of zakat management.

In carrying out its duties and functions, BAZNAS must to have a cooperation with related parties under the provisions of the Act of 23 of 2011. BAZNAS reports the results of its cooperation to the President through the Minister and to the House of Representatives of the Republic of Indonesia at least once a year. BAZNAS consists of 11 members. BAZNAS membership consists of 8 people from the elements of society and 3 people from government elements. Elements of society consist of elements of ulama, professionals, and public figures of Islam. The government element is appointed from the ministry / institution related to the management of zakat. BAZNAS is led by a chairman and a vice chairman. To assist BAZNAS in conducting the collection, distribution and utilization of zakat, the community can establish the Institute of Amil Zakat (LAZ). The LAZ establishment shall be authorized by the Minister or the official appointed by the Minister.

Various innovations in raising, managing and distributing zakat, infaq and alms funds have been done both by BAZIS and LAZIS, especially those in big cities. However, existing expectations will not be achieved if the Amil Zakat Institute does not have orientation in the utilization of zakat funds available.

In order to realize the benefits of zakat that is able to become pillars of economic, social, political, professional management of zakat becomes the main prerequisites that should not be abandoned. The key in efforts to improve the quality and quantity of ZISWAF (Zakat, Infaq, Sadaqah \& Waqf) as a productive and potential people fund is management. Management not only ceases to be empowered for productive enterprises and the need for priority-scale determination of utilization, but also requires transparency and accountability. The use of management in the collection of zakat aims to ensure the purpose of the deeds of charity can be achieved. According to Sherafat Ali Hashmi the existing management patterns can be implemented in the management of ZISWAF. The main role in this implementation lies in the existence of professional zakat institutions. By accommodating the principles of management, it is expected that the empowerment of Islamic philanthropy can be maximized. So the management-based management of zakat, not only talks about how to empower the zakat funds from the muzakki for the purpose of empowering mustahik. However, management-based zakat management covers all aspects related to the implementation of zakat as one of the pillars of Islam. In this case relates to the delivery of zakat teachings, collection, use, mustahik empowerment and zakat control. In the management of zakat, the collection and distribution of zakat are two things that are equally important to justice enforcement. John Rawls said: "Social and economic inequality must be regulated in such a way that it can be expected to benefit everyone (Prasetyo, 2006). There must be a balance of the interests of workers and employers contained in the legislation. The worker's interests are fulfilled the needs of his life and that of his 
family appropriately. At the same time, the benefits of entrepreneurs are the continuity of the business of the company to continue. Social justice should be regulated in the legislation in force, or in other words the positive law must pay attention to justice. (Prayitno, Rachmawati, \& Budiman, 2020).

Empirical studies in Indonesia, Firdaus, et al. (2012) estimated the potential of zakat in Indonesia and explored the relationship between demographic characteristics and zakat payment. Primary data were obtained through surveys in two cities and two districts consisting of 345 households, while secondary data were obtained from various sources. Empirical analysis is done through descriptive and multivariate analysis. The results show that the total of all the potentials of zakat in Indonesia is of variety sources of around $\mathrm{Rp} 217$ trillion. This figure is equal to 3.4\% of Indonesia's GDP in 2010. The study shows that education, employment and income are important factors that influence the frequency and choice of respondents when paying zakat and zakat.

Indonesia is applying the comprehensive model of the zakat that is a model where a country already has formal laws and regulations on zakat and has made zakat a duty that must be performed by its citizens.

This comprehensive model has seven characteristics, which include:

1. Has specific laws and regulations concerning zakat; law No. 23 of 2011 and Government Regulation No. 14 of 2014

2. Zakat has become a mandatory instrument in the view of state law;

The Zakat Management Act of 1999 was later amended by Law 4. The Government Presidential Instruction No. 3 of 2014 concerning Optimization of Zakat Collection in Ministries / Institutions, Regional Governments, BUMN and BUMD through BAZNAS

3. (Standardization of zakat collection, distribution, reporting and management system as a whole);

In carrying out its duties and functions BAZNAS may cooperate with related parties in accordance with the provisions of legislation. BAZNAS reports the results of its written duties to the President through the Minister and to the House of Representatives of the Republic of Indonesia at least once a year. BAZNAS consists of 11 members. The establishment of a government-sponsored zakat (BAZ) and community-run (LAZ) management agency, however, has made an important contribution to the increasing role and social responsibility of Islamic philanthropy in the country.

4. There are provisions regarding the zakat property that develops in all sectors of the national economy; Based on Law Number 23 Year 2011, BAZNAS was formed by the government in the task of implementing zakat management authority nationally. The authority to carry out the collection, distribution, and utilization of zakat nationally covers 4 (four) functions specifically set forth in

Law Number 23 of 2011, as follows: (a) functions of planning the collection, 
distribution and utilization of zakat; (b) the function of carrying out the collection, distribution and utilization of zakat; (c) the function of controlling the collection, distribution and utilization of zakat; and (d) the function of reporting and accountability for the management of zakat (Article 7).

5. Efficient and integrated institutional structure of zakat: from the Decisision of Indonesian Constitutional Court granted the request for article 18 paragraph (2) letter $a$ and letter $b$ which contained the requirements for the establishment of LAZ, namely by providing information that among the requirements were "registered as an Islamic community organization that manages the fields of education, preaching, and social , or a legal entity, must obtain permission from the authorized official,;

6. The integration of zakat instruments in fiscal policies and the overall economic economic system;

7. The implementation of good amil governance as an effort to strengthen zakat governance.

When looking at some Southeast Asian countries, the collection of zakat in neighboring countries has progressed quite well. An example is Malaysia State. The potential of zakat in Malaysia every year increases. Zakat collection in Malaysia is managed by the Zakat Pollution Center (PPZ) under the Majelis Agama Islam Wilayah Persekutuan Kuala Lumpur (MAIWP), or under the direct supervision of the Majelis Agama Islam in every state of which there are 14 pieces, and every Islamic Religious Council has employees of the Islamic Religion Office.

Using aggregate data in Malaysia, Suprayitno et al. (2013) found that zakat that is distributed systemically has a positive impact on aggregate consumption. Therefore, the distribution of zakat must not be limited to consumption needs, but must also be covered by other forms of monetary assistance that can generate a continuous income stream for the recipient of zakat.

Still in Malaysia in a study, Sadeq (1996) reported that around 73 percent of the estimated collection of zakat potential is needed each year to change the status of poor households to the status of non-poor households again in Malaysia. Ibrahim (2006) added that the distribution of zakat in Malaysia has reduced the income inequality of Malaysian people. His analysis shows that the distribution of zakat reduces the chances of a community falling at the level of the poverty line and reduces the severity of poverty in Malaysia.

All aspects related to the zakat administration is running by the states through the State Islamic Religious Councils (SIRC), respectively. This is due to the fact that the ninth schedule of the federal constitution of Malaysia recognizes the rights of religious affairs in the state, not federal. Therefore, administration of zakat is under the jurisdiction of the respective states or the prerogative of monarchs. As a result, management and administration of zakat vary by state. Each state has its own zakat 
institution. The main task of these institutions is managing all affairs pertaining to zakat such as zakat law and its enforcement, zakat collection method, disbursement policy, administrative aspects and execution (Nurbarizah, 2007). Usually, zakat institution will operate based on the advice and rulings issued by the ruling or fatwa under the respective State Islamic Religious Council (SIRC). The Fatwa Council is also a point of reference for zakat institution in carrying out their operations and is ultimately responsible for formulating and issuing a fatwa to be implemented by the institutions. Thus, each state has its own zakat law, which is considered part of the state enactments.

Efficiency which refers to how well zakat institutions are using its resources to meet its objectives of socioeconomic justice (e.g. reducing poverty) and governance which refers to the process and structure in directing and managing the affairs of the zakat institution have been argued as one means in demonstrating accountability to the zakat payers and ultimately to Allah, whilst taking into consideration the requirements of the shari'ah (Norazlina \& Rahim, 2011). Norazlina \& Rahim (2011) argue that the governance of zakat institutions here refers to the governance structure and mechanism to ensure financial and managerial accountability of zakat collection and distribution. They also argue that in order to be accountable, to the public as well as to institutional stakeholders, organizations need to be fully transparent by ensuring processes, institutions and information are accessible to those concerned with them and enough information should be provided to stakeholders for monitoring purposes.

On the other hand, the roles and responsibilities of the zakat institutions is not only important for them to be accountable but to demonstrate how accountable they are in fulfilling their tasks to the public, zakat payers, other stakeholders and ultimately to Allah. Hence, we argued that zakat institutions accountability system and practice is vital as it partially determine, to a great extent, who, what, and how they are going to account to (Haniffa, 2002; Lewis, 2006) in distributing zakat, which include for example, the 'Asnaf' and the zakat payers. Despite the possible impact of accountability system and practice could have on the zakat institutions few empirical studies have been undertaken on zakat institutions accountability system and practices and examine the impact it has on the effectiveness and efficiency of zakat institutions in managing zakat fund.

\section{E. CONCLUSION}

Zakat is an important mechanism for the development of the country as it contributes to social security and harmony to help bridge the gap between the rich and the poor as well as to strengthen the economic independence of the Muslim community. It is also an important financial resource for an Islamic state in addition to the tax funds. Generally speaking, the distribution of zakat funds could help the government to generate economic activity through an increase in individual's purchasing power and finally help to alleviate poverty. . Zakat funds could be used to improve the living 
standards of the people who have low income households. Given the importance of zakat to the economy and society, in countries like Indonesia, Malaysia, and Singapore zakat institutions have been set up to collect and distribute funds. They are under the controlled by government that play an important role in the administration and management of zakat. It is obvious that Indonesia must comply the law of management zakat in Malaysia and Singapore, the management of zakat law in neighboring countries are much better in distributions way hence Indonesia is better in the management of zakat.

\section{ACKNOWLEDGEMENT}

This paper is fully funded under Matching Grant Between Universiti Utara Malaysia and Universitas Pasundan entitled The Effeciency Of Financial Management And Zakat Distibution in Malaysia and Indonesia.

1. Profesor and Senior Lecturer at Magister Notary, Universitas Pasundan

2. Professor at College Of Business, University Utara Malaysia

Students of Magister Notary, Universitas Pasundan

\section{REFERENCES}

1. Ali, E. M. T. E. (2011, November). Ke arah penyeragaman Undang-undang dan peraturan berkaitan zakat di Malaysia. 1st Zakat Conference IKAZ (2011) PWTC (pp. 22-24).

2. Al-Jurjani. (1985). al-Ta'rifat. Beirut: Maktabah Lubnan.

3. Al-Nawawi, \& Yahya. (2007). al-Majmu' Syarh al-Muhadhdhab. Beirut: Dar al-Kutub al- Ilmiyyah.

4. Al-Qaradhawi, Y. (2006). Fiqh Zakat. Kaherah: Maktabah Wahbah.

5. Al-Qurtubi, \& Muhammad. (Without Year). Bidayah Mujtahid. Kaherah: Maktabah al- Taufiqiyyah

6. Al-Sabhany. (2001). The Justice of Distribution and Economic Efficiency in Secular Systems and Islam: A Comparative Perspective. Journal of Shari'a and Law, al-Ain: UAE University.

7. Al-Solahin, \& al-Majid, A. (2007). Al-Adalah al-Tawzi'iyyahfi Nizam al-Mali al-Islami. Majallah al- Syariahwa al-Qanun. Al-'Ain: UAE University.

8. Al-Suyuthi, \& al-Din, J. (1983). Al-Asybahwa al-Nazair. Beirut: Dar al-Kutub al'Ilmiyyah.

9. Al-Zuhaili, \& Wahbah. (2006). Qadaya al-Fiqhwa al-Fikr al-Mu'asir. Beirut: Dar alFikr.

10. Beik, \& Syauqi, I. (2015). Towards International Standardization of Zakat System. Bogor: Bogor Agricultural University.

11. Beik, \& Syauqi, I. (2015). Ekonomi Pembangunan Syariah. Bogor: IPB Press.

$$
\begin{gathered}
\text { IJSOC } \odot 2020 \\
\text { http://ijsoc.goacademica.com }
\end{gathered}
$$

12. Che Yaacob, A., Daud, R., Mohamad, R., Shah Basri, B. S., \& Mohamed, S. (2011). Model Transformasi Agihan Zakat. Paperwork in The World Universities 1st Zakat Conference (IKAZ) 2011 PWTC, Kuala Lumpur, 22-24th of November 2011. 
13. National Amil Zakat Agency. (2020). Arsitek Zakat Indonesia. Jakarta: Badan Amil Zakat Nasional.

14. Permana, S., Subarsyah, T., Firdatunnisa, E. (2020). Implementation of Article 87 Law Number 2 of 2004 Concerning Resolution of Industrial Relations in the Court of Industrial Relations in Article of the Republic of Indonesia. International Journal of Science and Society, 2(3), 198-211.

15. Prayitno, S., Rachmawati, M. I., \& Budiman, B. D. (2020). Implementation of Fairness Theory in Minimum Wages Policy for Small and Medium Enterprise in Indonesia. International Journal of Science and Society, 2(3), 184-197.

16. Qardhawi, Y. (2004). Manajemen Zakat Profesional, Alih Bahasa Jasiman, dan Fauzan. Solo: Media Insani Press.

17. Zaidan, A. K. (2012). Al-Wajiz fi Usul al-Fiqh. Beirut: Muassasah al-Risalah Nasyirun.

18. Zakaria, A. (Without Year). Asna al-Matalib fi SyarhRawd al-Talib. Beirut: Dar al-Kitab al-islami. 